\title{
STANMORE CUSTOM-MADE EXTENDIBLE DISTAL FEMORAL REPLACEMENTS
}

\author{
CLINICAL EXPERIENCE IN CHILDREN WITH PRIMARY MALIGNANT BONE TUMOURS
}

OLIVER S. SCHINDLER， STEPHEN R. CANNON， TIMOTHY W. R. BRIGGS， GORDON W. BLUNN

From the Royal National Orthopaedic Hospital, Stanmore, England

The use of extendible distal femoral replacements is a relatively new treatment alternative for malignant bone tumours in growing individuals. Although their appearance was widely appreciated, questions about functional practicality and longevity remain unclear. With longer follow-up, advantages of immediate functional restoration and beneficial psychological aspects seem to be overshadowed by an increase in complications such as aseptic loosening, infection or prosthetic failure.

We have reviewed 18 children with such tumours who were treated between 1983 and 1990 by custom-made Stanmore extendible distal femoral replacements. Four died from metastatic disease within 2.5 years of operation and two required amputation for local recurrence or chronic infection.

The remaining 12 patients were followed for a mean of 8.7 years (6 to 13.2). A mean total lengthening of $5.2 \mathrm{~cm}$ was achieved, requiring, on average, 4.3 operations. Using the Musculoskeletal Tumor Society rating score the functional result at review was, on average, $77 \%$ of the expected normal function, with seven patients achieving $\geq 80 \%$. Revision of the prosthesis was required in ten patients, in six for aseptic loosening, at a mean of 6.2 years after the initial procedure.

J Bone Joint Surg [Br] 1997;79-B:927-37.

Received 15 August 1996; Accepted after revision 3 July 1997

O. S. Schindler, MD, Senior Registrar in Orthopaedic Surgery

S. R. Cannon, FRCS, Consultant Orthopaedic Surgeon

T. W. R. Briggs, FRCS, Consultant Orthopaedic Surgeon

Bone Tumour Unit

G. W. Blunn, PhD, Chief Deputy of Research

Department of Biomedical Engineering

Royal National Orthopaedic Hospital, Brockley Hill, Stanmore, Middlesex HA7 4LP, UK.

Correspondence should be sent to Dr O. S. Schindler at 24 Blackwood Crescent, Edinburgh EH9 1QX, UK.

(C)1997 British Editorial Society of Bone and Joint Surgery 0301-620X/97/67164\$2.00
The distal end of the femur is the most common site of primary malignant tumours of bone in children. The recent improvement in survival rate after operation for osteosarcoma and Ewing's sarcoma is mainly due to the use of modern chemotherapy. More accurate diagnostic assessment of the tumour has allowed preservation of the limbs rather than amputation in most cases without any adverse effect on survival. ${ }^{1}$

In 1986 Simon et $\mathrm{al}^{2}$ showed that the results of limb salvage were comparable to above-knee amputation in high-grade tumours of the distal femur. Since then prosthetic reconstruction with limb salvage has shown a local recurrence rate of between $5 \%$ and $10 \%$, comparable to that achieved with radical ablation. ${ }^{2-10}$ Nevertheless, encroachment of the tumour on major neurovascular structures in the popliteal fossa, pathological fractures with subsequent contamination of multiple tissue compartments and local recurrence after operations to preserve the limb usually result in amputation. ${ }^{11-13}$

The use of extendible endoprosthetic replacements for tumours around the femur is now an established and safe alternative to above-knee amputation. The extension module compensates for discrepancies of growth in patients who would otherwise develop an incapacitating inequality of leg length if given a fixed-length implant. ${ }^{14-17}$ The integrity of the femur is restored allowing early rehabilitation and resumption of walking. ${ }^{14}$ There is a positive functional and psychological impact which is important in patients with a disease which has a high mortality. ${ }^{18,19}$

The design of the Stanmore 'growing prosthesis' has changed over the last two decades. In the early types (1982-88) lengthening was achieved by insertion of ballbearings and later (1988-1994) by exchange of metal spacers (C-clips) of variable length. ${ }^{17,20,21}$ Both were difficult to use. The more recent model (Mark IV) includes a telescopic worm-wheel screw mechanism operated with a key needing only a minor operation. Development of a better replacement which allows extension without surgery is underway. ${ }^{22,23}$

Previous reports have indicated limited longevity and a high rate of revision in extendible distal femoral replacements, mainly due to aseptic loosening, infection and fail- 
ure of the prosthesis. ${ }^{24-27}$ Fixed-length distal femoral replacements have been used successfully in tumour surgery for many years with good results, but there are few reports on extendible variants ${ }^{28,29}$ and most of them report few patients with limited follow-up. ${ }^{15,25,27,30-32}$

We have reviewed our experience with the Stanmore prosthesis which has been used at the Royal National Orthopaedic Hospital since 1983.

\section{PATIENTS AND METHODS}

Between April 1983 and December 1990 we treated 18 patients (10 boys and 8 girls) with high-grade primary malignant tumours of the lower femur by resection of the lesion and replacement with an extendible distal femoral endoprosthesis. Their mean age was 11 years (8 to 14 ).

Careful staging was undertaken using radiographs and MRI of the involved leg, whole-body Tc scanning and CT of the chest to define the extent of the tumour, the presence of skip lesions and to exclude bony or pulmonary metastases. ${ }^{33-36}$ None had established metastases on initial staging. Angiography was used to assess encroachment on the blood vessels if the MRI was inconclusive. Percutaneous needle biopsies were carried out under radiological control and guidance by the surgeon to ensure that the biopsy track could be incorporated in the tumour resection. ${ }^{37-39}$ There were 17 osteosarcomas, one parosteal and 16 osteogenic, and one Ewing's sarcoma, all of which were classified as stage-IIB lesions, except the parosteal osteosarcoma which was IB. ${ }^{33}$ The lesions were resected en bloc with a wide margin of bone of about $5 \mathrm{~cm}$ proximal to the defined limits of the tumour. ${ }^{40}$ The attachment of the patellar tendon at the tibial tuberosity and the quadriceps mechanism were preserved in all but two patients. We overlengthened the prosthetic replacement at insertion by 1 to $2 \mathrm{~cm}$, avoiding damage to neurovascular structures, to reduce the number of further lengthening procedures.

All patients had chemotherapy before and after operation. Additional radiotherapy was used only for the patient with Ewing's sarcoma. After operation a plaster back slab was used for the first 24 hours, after which the patients had continuous passive motion and bedside physiotherapy. ${ }^{41}$ Mobilisation began after five to ten days as soon as the abductors and the quadriceps had sufficient function. The mean hospital stay was 26 days (16 to 46), and after discharge physiotherapy continued until no further progress was seen. Follow-up was every three months for the first two years, every six months for the next three years and

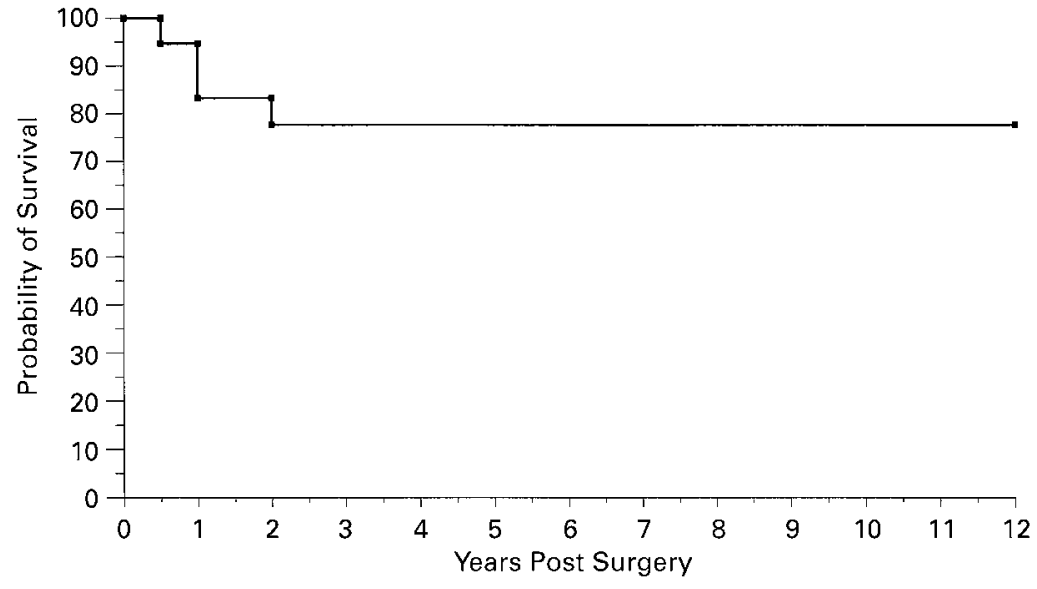

Fig. 1a

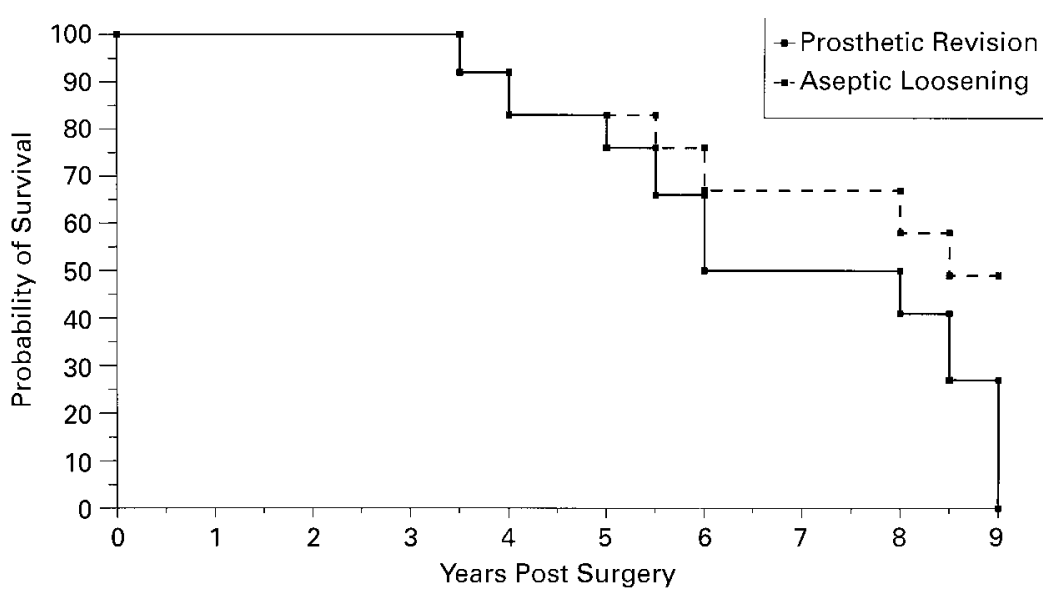

Fig. 1b
Figure 1a - Overall probability of survival in 18 patients with malignant bone tumours after tumour resection and distal femoral replacement. Figure $1 \mathrm{~b}-$ Probability of surviving revision of the prosthesis compared with the probability of surviving aseptic loosening. 
Table I. The Musculoskeletal Tumor Society rating score in accordance with the International Symposium on Limb Salvage in Musculoskeletal Oncology 47

\begin{tabular}{|c|c|c|c|c|c|c|c|}
\hline Score & Pain & Walking & Supports & & Gait & $\begin{array}{l}\text { Emotional } \\
\text { acceptance }\end{array}$ & Function \\
\hline 5 & None & Unlimited & None & & Normal & Enthused & No restrictions \\
\hline 4 & & & & Intermediate & & & \\
\hline 3 & Modest & Limited & Brace & & Minor cosmetic & Satisfied & Recreational restrictions \\
\hline 2 & & & & Intermediate & & & \\
\hline 1 & Moderate & Inside only & 1 cane or crutch & & Major cosmetic Minor HCAP* & Accepts & Partial disability \\
\hline 0 & Severe & Unable unaided & 2 canes or crutches & & Major HCAP & Dislikes & Total disability \\
\hline
\end{tabular}

* handicap

subsequently annually. At each review, functional ability was assessed and leg length measured.

To analyse the outcome we used a survivorship table which gives an estimation of the annual failure rate. ${ }^{42,43}$ Failure was defined as the onset of moderate pain, revision of the replacement or amputation. Overall survival of the patients and survival of the prosthesis after revision of the prosthesis for loosening were also estimated (Fig. 1). ${ }^{44,45}$

We determined clinical function according to the Musculoskeletal Tumor Society rating score (MTSRS) advocated by Enneking in 1985 and revised in $1993 .{ }^{46,47}$ This assesses pain, function, emotional acceptance, support, walking ability and gait. The more recent system is based on quantitative measurements whereas its predecessor used qualitative descriptive terms.
In the current study we applied both systems to allow comparisons with other reports since all available studies have used the descriptive methods (Table I).

Prostheses. We used two generations of growing prostheses incorporating different extension mechanisms (Mark II and Mark III) (Stanmore Implants Worldwide, Department of Biomedical Engineering, Institute of Orthopaedics, Stanmore, UK). All were individually designed according to the dimensions of the distal femur to be resected. In 1982 the first widely used second generation of extendible replacements incorporating the Stanmore Mark II extension mechanism was introduced (Fig. 2). ${ }^{16,20}$ This had a telescopic shaft which could be extended by the introduction of tungsten-carbide ball-bearings into a cylinder; each ball pushed a piston down by $6.35 \mathrm{~mm}$ (Figs 2, 4, 6 to 8 ).
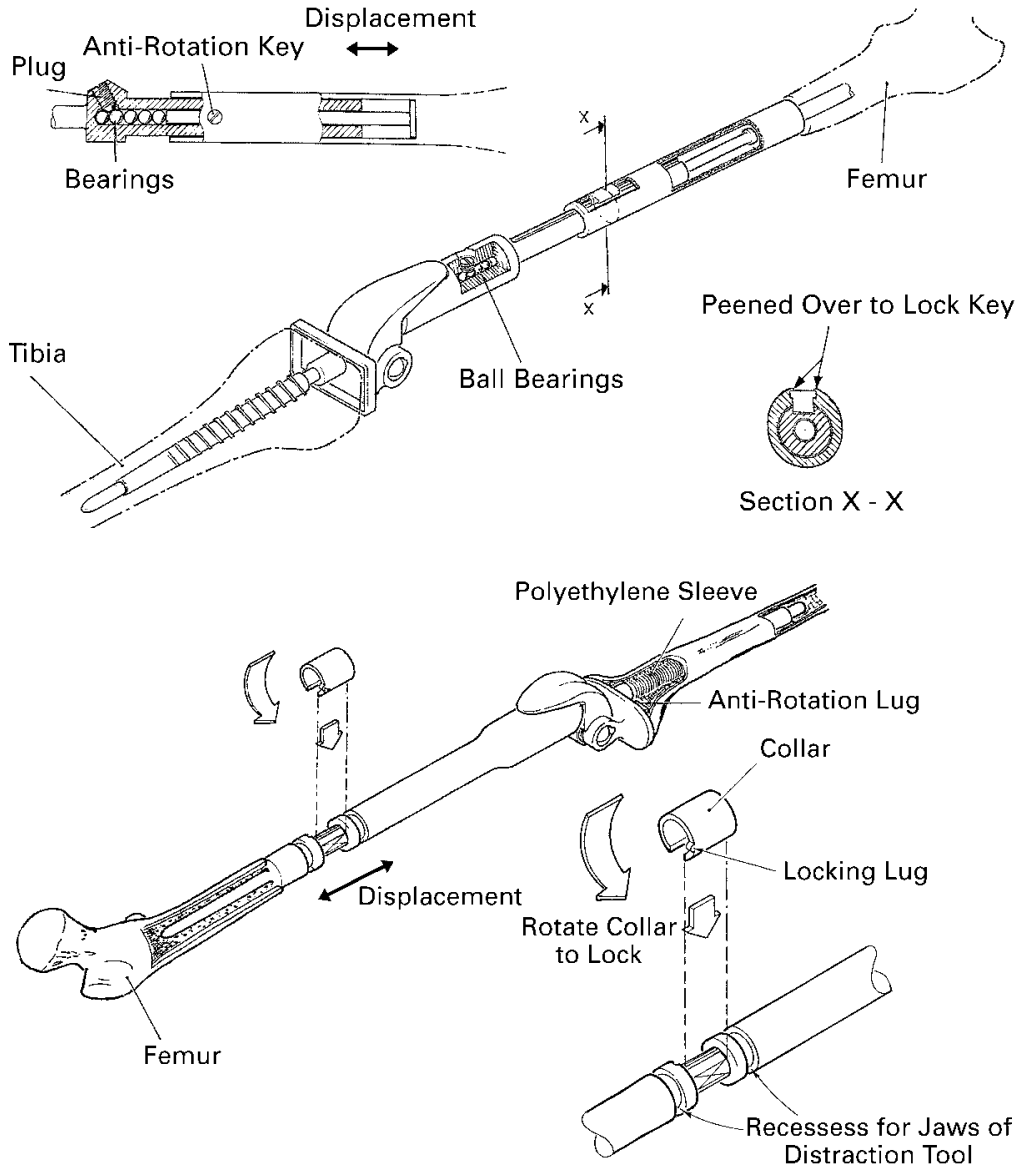

Fig. 2

Exploded view of a Stanmore Mark II endoprosthetic replacement with ball-bearing extending mechanism, produced between 1982 and 1988. The longitudinal section shows some minor design modifications in a later version with a decreased introduction angle for the ball-bearings and bilateral anti-rotation keys.

Fig. 3

Exploded view of a Stanmore Mark III endoprosthetic replacement with collar type (C-clip) extending mechanism, used between 1988 and 1994 . 


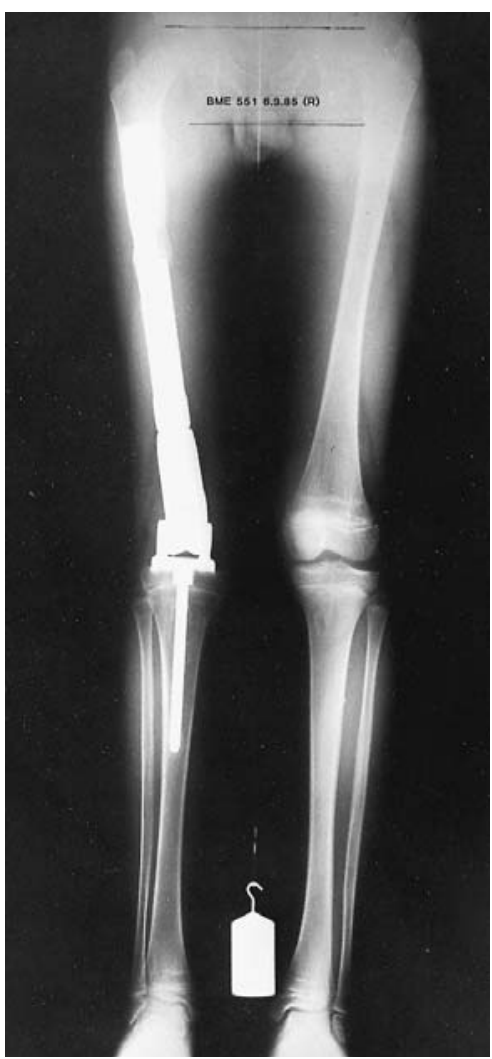

Fig. 4

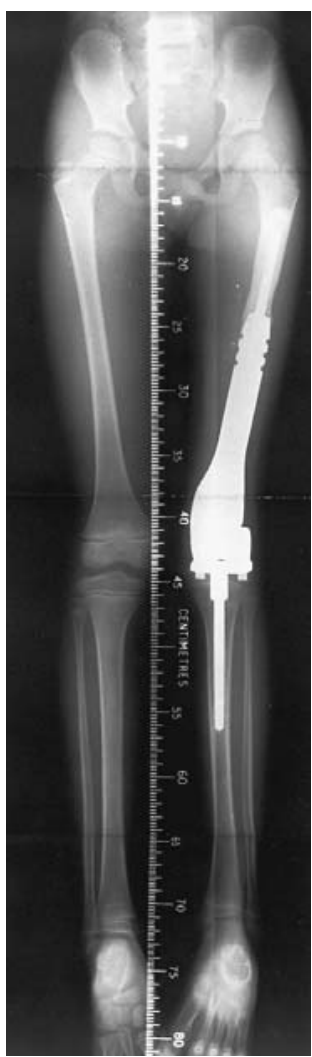

Fig. 5
Figure 4 - Anteroposterior radiograph 18 months after implantation of a Stanmore Mark II extendible prosthesis replacing the right distal femur. Figure 5 - Anteroposterior radiograph 22 months after implantation of a Stanmore Mark III extendible prosthesis replacing the left distal femur.
Mechanical failure due to ball breakage led to the development of a more simple mechanism, the Stanmore Mark III 'collar type' in 1988 (Fig. 3). ${ }^{19}$ This used ring spacers, allowing lengthening by insertion of C-clips, each $6 \mathrm{~mm}$ wide, on to a telescopic axle (Figs 3 and 5). Every extension required partial reopening of the wound and the distance was set by the fixed length of the spacers.

The distal femoral prosthesis connects with a fullyconstrained Stanmore Mark 5 knee in which a hinge mechanism allows flexion and extension between $0^{\circ}$ and $125^{\circ}$ (Figs 2 and 3). The tibial stem slides into an ultra-highmolecular-weight polyethylene (UHMWP) sleeve which is screwed without cement into the bone beyond the epiphyseal plate. This allows the distribution of radial forces in the tibial canal over a wider surface, avoids micromotion between the stem and the bone and preserves the potential for growth at the proximal tibial physis since the stem can slide within the sleeve. ${ }^{19,48}$

The extension modules, shafts and stems were made of titanium alloy type TA/1 containing $6 \%$ aluminium and $4 \%$ vanadium. This material has proved stronger than its predecessor TI160 (T5) use of which was discontinued after the breakage of two stems in fixed-stem prostheses. ${ }^{28}$ The distal femoral condyles, the hinge mechanism and part of the tibial component were made of cobalt-chrome-molybdenum alloy (Co-Cr-Mo) which is much harder than titanium and has better wear characteristics on bearing surfaces especially with UHMWP. The combination of Co-Cr-Mo and TA/1, which is much lighter, allows the production of endoprostheses of a reasonable weight but avoids the dis-

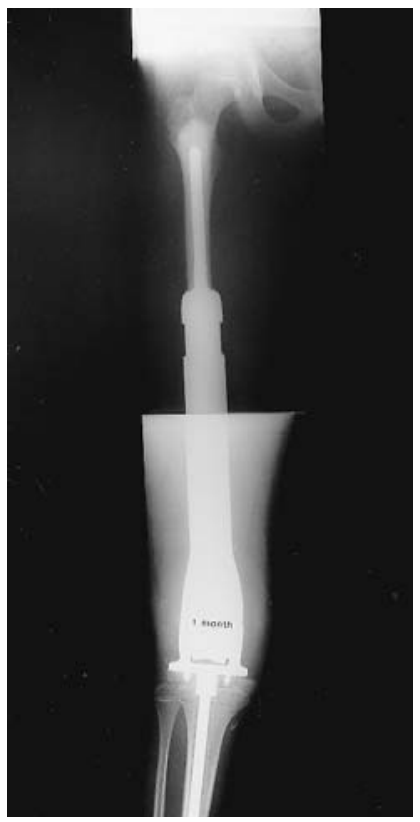

Fig. 6

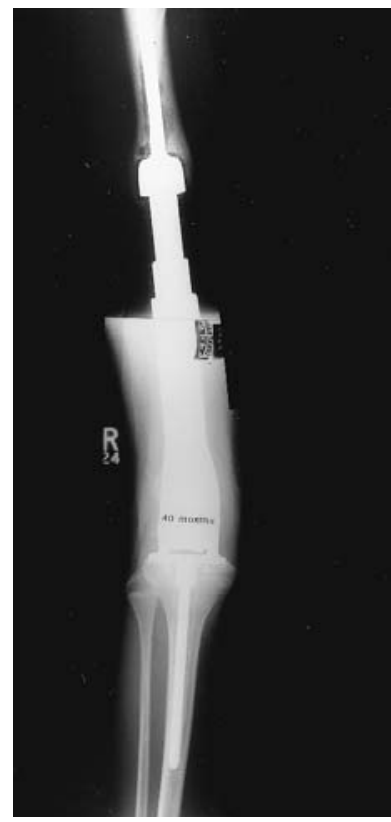

Fig. 7

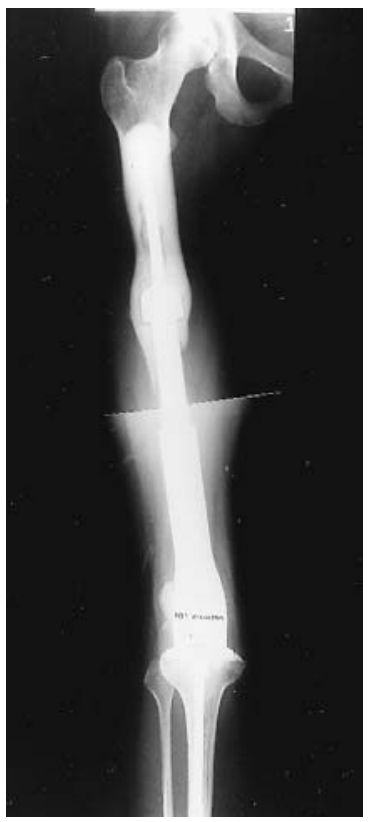

Fig. 8

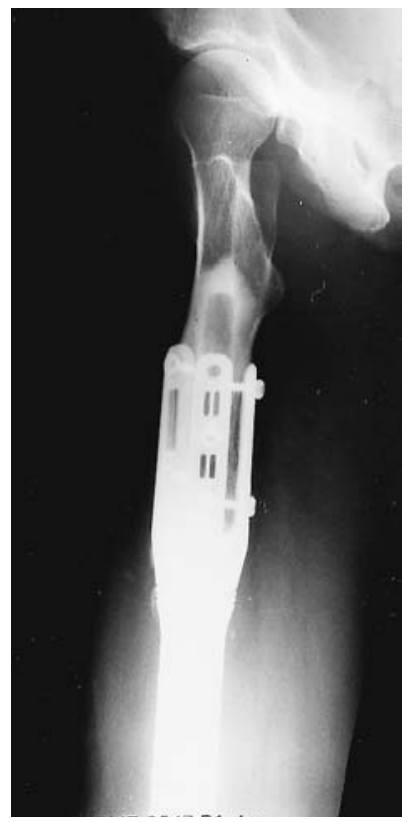

Fig. 9

Figures 6 to 8 - Sequential radiographs showing a Stanmore Mark II extendible distal femoral replacement at 1 , 40 and 101 months after implantation. At 101 months extension of $5.7 \mathrm{~cm}$ was achieved and revision was necessary because of loosening of the femoral component. Figure 9 - A lateral radiograph of the proximal femur 16 months after prosthetic revision for aseptic loosening. The prosthetic stem of the implanted Stanmore Mark IV prosthesis has uncemented screw fixation using hydroxyapatite-coated flanges. 
Table II. Survivorship table with failure defined as having severe pain or undergoing revision or amputation

\begin{tabular}{|c|c|c|c|c|c|c|c|}
\hline \multirow{2}{*}{$\begin{array}{l}\text { Years since } \\
\text { operation }\end{array}$} & \multirow{2}{*}{$\begin{array}{l}\text { Number } \\
\text { at start }\end{array}$} & \multicolumn{2}{|c|}{ Result at last review } & \multirow{2}{*}{$\begin{array}{l}\text { Number } \\
\text { at risk }\end{array}$} & \multirow{2}{*}{$\begin{array}{l}\text { Annual failure } \\
\text { rate }(\%)\end{array}$} & \multirow{2}{*}{$\begin{array}{l}\text { Annual success } \\
\text { rate }(\%)\end{array}$} & \multirow{2}{*}{$\begin{array}{l}\text { Cumulative } \\
\text { success rate }(\%)\end{array}$} \\
\hline & & Success & Failure & & & & \\
\hline 0 to 1 & 18 & 3 & 1 & 16.5 & 6.1 & 93.9 & 93.9 \\
\hline$>1$ to 2 & 14 & 1 & 1 & 13.5 & 7.4 & 92.6 & 86.9 \\
\hline$>2$ to 3 & 12 & 0 & 0 & 12 & 0.0 & 100.0 & 86.9 \\
\hline$>3$ to 4 & 12 & 0 & 2 & 12 & 16.6 & 83.4 & 72.5 \\
\hline$>4$ to 5 & 10 & 0 & 1 & 10 & 10.0 & 90.0 & 65.2 \\
\hline$>5$ to 6 & 9 & 0 & 3 & 9 & 33.3 & 66.7 & 43.5 \\
\hline$>6$ to 7 & 6 & 0 & 0 & 6 & 0.0 & 100.0 & 43.5 \\
\hline$>7$ to 8 & 6 & 1 & 1 & 5.5 & 18.1 & 81.9 & 35.6 \\
\hline$>8$ to 9 & 4 & 1 & 2 & 3.5 & 57.1 & 42.9 & 15.3 \\
\hline$>9$ to 10 & 1 & 0 & 1 & 1 & 100.0 & 0.0 & 0.0 \\
\hline
\end{tabular}

advantage of the increased wear of titanium at bearing surfaces.

We are currently using the Mark IV prosthesis which incorporates a growth module based on a worm-wheel screw mechanism, operated by an AO screwdriver used at a minimally invasive procedure (Fig. 9). The knee component (SMILES; Stanmore Modular Individualised Lower Extremity System) has also been redesigned using a double bearing surface which allows some rotation. ${ }^{49}$

\section{RESULTS}

Our overall survival rate is shown in Figure 1a. The $83 \%$ probability of patient survival at one year after surgery decreased to $77.6 \%$ at two years, but did not change thereafter. Prosthetic survival analysis using the criteria listed above showed a cumulative success rate of $93.9 \%$ at the first year, decreasing to $65.2 \%$ at five years and to zero at ten years. The cumulative $100 \%$ failure rate for prostheses at ten years illustrates the high level of complications encountered (Table II).

The mean follow-up was 8.7 years (6.0 to 13.2$)$, and all but one of the 12 surviving patients who did not undergo amputation had reached maturity at the latest review at a mean age of 19.8 years.

There were 12 failures: ten partial or complete revisions and two amputations. Revision was performed at a mean of 6.2 years (3.5 to 9.0) after the primary operation. The probability of survival of a revised prosthesis after five years was estimated at $76 \%$, decreasing to $41 \%$ at eight years and to zero at nine years (Fig. 1b). The probability of survival of a prosthesis revised for aseptic loosening after five years was $83 \%$, decreasing to $46 \%$ at 8.5 years (Fig. 1b). In six patients aseptic loosening of the femoral or tibial stem required revision at a mean of 5.7 years (3.8 to 8.4). One child had a revision at eight months because of local recurrence of the tumour and another at 8.6 years for failure of the prosthesis. In this patient one of the tungsten-carbide balls of the Mark II prosthesis had broken, jamming the extending mechanism; use of this type of prosthesis was therefore abandoned. ${ }^{19}$ In two patients a new extending mechanism was installed to allow further growth after the original one had been fully lengthened. In another the tibial component was revised and a long-stem version inserted after a stress fracture below the original intramedullary fixation. The mean percentage of femur replaced in patients who had revisions for aseptic loosening of the proximal stem was $57.8 \%+5.3 \%$ compared with $46.2 \%+7.0 \%$ in all others.

Of the two patients who required amputation, one had local recurrence of the tumour (Figs 10 and 11) and the other had an uncontrollable chronic infection.

One other patient also had a local recurrence. Seven developed heterotopic metastases, mainly in the lungs; four subsequently died of related complications; the other three had metastectomies and are currently free from disease.

Table III gives the clinical results rated according to the

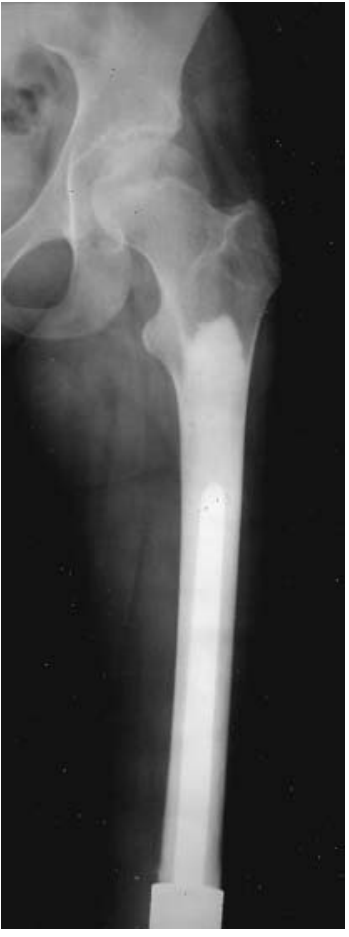

Fig. 10

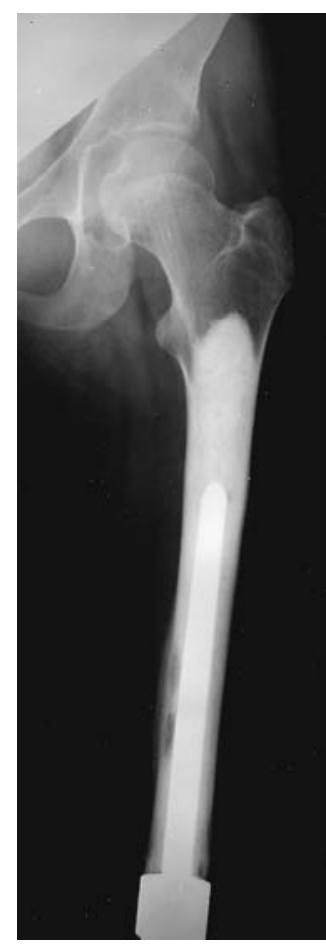

Fig. 11
Figure 10 - Anteroposterior radiograph showing the femoral fixation of an extendible distal femoral replacement at seven months after implantation. Histological investigation confirmed complete excision of an osteogenic sarcoma with a wide margin. Figure 11 - AP radiograph of the same patient as in Figure 7, 13 months after surgery. There are signs of local recurrence of the tumour around the medial femoral cortex; amputation was needed. 
Table III. Details of 18 patients

\begin{tabular}{|c|c|c|c|c|c|c|c|c|c|c|c|}
\hline Case & Sex & $\begin{array}{l}\text { Age at } \\
\text { operation } \\
(y r)\end{array}$ & Pathology* & Site & $\begin{array}{l}\text { Adjuvant } \\
\text { therapy }\end{array}$ & $\begin{array}{l}\text { Type of } \\
\text { prosthesis } \dagger\end{array}$ & $\begin{array}{l}\text { Femur } \\
\text { replaced } \\
(\%)\end{array}$ & $\begin{array}{l}\text { Amount } \\
\text { extended (mm) } \\
\text { /procedures }\end{array}$ & $\begin{array}{l}\text { Amount of } \\
\text { shortening } \\
(\mathrm{mm})\end{array}$ & $\begin{array}{l}\text { Local } \\
\text { recurrence/ } \\
\text { metastasis }\end{array}$ & $\begin{array}{l}\text { Follow-up } \\
\text { (mth) }\end{array}$ \\
\hline 1 & M & 12 & OG-OS/IIB & $\mathrm{R}$ & Chemo & Mark II & 58 & $54 / 4$ & 20 & No/No & 143 \\
\hline 2 & M & 10 & OG-OS/IIB & $\mathrm{R}$ & Chemo & Mark II & 59 & $44 / 3$ & 35 & Yes/No & 158 \\
\hline 3 & $\mathrm{~F}$ & 8 & PA-OS/IB & $\mathrm{R}$ & Chemo & Mark III & 52 & $60 / 5$ & 15 & $\mathrm{No} / \mathrm{No}$ & 72 \\
\hline 4 & M & 12 & OG-OS/IIB & $\mathrm{R}$ & Chemo & Mark III & 52 & $54 / 4$ & 20 & $\mathrm{No} / \mathrm{No}$ & 98 \\
\hline 5 & $\mathrm{~F}$ & 13 & OG-OS/IIB & $\mathrm{R}$ & Chemo & Mark III & 40 & $30 / 2$ & 15 & $\mathrm{No} / \mathrm{No}$ & 80 \\
\hline 6 & M & 10 & OG-OS/IIB & $\mathrm{R}$ & Chemo & Mark III & 48 & $54 / 5$ & 10 & No/Yes & 75 \\
\hline 7 & M & 11 & OG-OS/IIB & $\mathrm{L}$ & Chemo & Mark III & 35 & $60 / 6$ & 5 & $\mathrm{No} / \mathrm{No}$ & 95 \\
\hline 8 & M & 13 & Ewing's/IIB & $\mathrm{L}$ & Chemo/Radio & Mark III & 65 & $54 / 6$ & 0 & $\mathrm{No} / \mathrm{No}$ & 95 \\
\hline 9 & M & 12 & OG-OS/IIB & $\mathrm{R}$ & Chemo & Mark II & 40 & $38 / 3$ & 20 & No/Yes & 119 \\
\hline 10 & $\mathrm{~F}$ & 8 & OG-OS/IIB & $\mathrm{R}$ & Chemo & Mark II & 60 & $57 / 5$ & 30 & No/No & 121 \\
\hline 11 & $\mathrm{~F}$ & 8 & OG-OS/IIB & $\mathrm{L}$ & Chemo & Mark II & 53 & $70 / 6$ & 0 & No/No & 105 \\
\hline 12 & $\mathrm{~F}$ & 11 & OG-OS/IIB & $\mathrm{R}$ & Chemo & Mark III & 51 & $48 / 3$ & 5 & $\mathrm{No} / \mathrm{No}$ & 96 \\
\hline Mean & & 11 & & & & & 51 & $52 / 4.3$ & 14.5 & & 104.7 \\
\hline 13 & $\mathrm{~F}$ & 13 & OG-OS/IIB & $\mathrm{L}$ & Chemo & Mark III & 45 & Nil & 0 & Yes/Yes & 13 \\
\hline 14 & M & 14 & OG-OS/IIB & $\mathrm{R}$ & Chemo & Mark II & 62 & Nil & 0 & $\mathrm{No} / \mathrm{No}$ & 8 \\
\hline 15 & $\mathrm{~F}$ & 12 & OG-OS/IIB & $\mathrm{R}$ & Chemo & Mark II & 55 & Nil & +10 & No/Yes & 3 \\
\hline 16 & M & 9 & OG-OS/IIB & $\mathrm{R}$ & Chemo/Radio & Mark III & 59 & Nil & 0 & No/Yes & 12 \\
\hline 17 & $\mathrm{~F}$ & 12 & OG-OS/IIB & $\mathrm{R}$ & Chemo & Mark III & 44 & Nil & 0 & No/Yes & 24 \\
\hline 18 & M & 10 & OG-OS/IIB & $\mathrm{R}$ & Chemo & Mark III & 51 & Nil & 0 & No/Yes & 7 \\
\hline
\end{tabular}

* OG-OS, osteogenic osteosarcoma; PA-OS, parosteal osteosarcoma; Ewing's: Ewing's sarcoma

$\dagger$ Mark II, ball-bearing type; Mark III, C-clip spacer type. All types connected to Stanmore Mark-5 fixed-hinge knee component (see text)

\$ AL-FC, aseptic loosening of femoral component; AL-TC, aseptic loosening of tibial component; FRC, bone fracture; INF, infection; LR, local recurrence; MEM, maximised extending mechanism; $\mathrm{PF}$, prosthetic failure

§ IDP, independent; EC, elbow crutch; WS, walking stick; HKB, hinged knee brace; FKB, fixed knee brace

I CDF, continuously disease-free; NED, no evidence of disease at present but recurrence or metastasis in the past; X, died

II PM, pulmonary metastectomy; MUA, manipulation under anaesthesia

Table IV. Functional results according to MTSRS criteria

\begin{tabular}{lcl}
\hline $\begin{array}{l}\text { MTSRS } \\
\text { criteria }\end{array}$ & $\begin{array}{l}\text { Average } \\
\text { score }\end{array}$ & Percentage* \\
\hline Pain & 4.6 & 92 \\
Walking & 3.8 & 76 \\
Supports & 4.3 & 86 \\
Gait & 3.7 & 74 \\
Emotional acceptance & 3.3 & 66 \\
Function & 3.5 & 70 \\
Mean & 23.3 & 77.6 \\
\hline
\end{tabular}

* proportion of expected normal function

MTSRS criteria in Table I. Seven patients had excellent results $(59 \%)$, three good $(25 \%)$ and two fair (16\%); using the new MTSRS criteria, seven patients scored $\geq 80 \%$, three between $73 \%$ and $76 \%$, one $56 \%$ and another $46 \%$. On average, the overall functional outcome was estimated at $77 \%$ of the expected normal function (Table IV).
All 12 patients were actively lengthened, averaging 4.3 procedures each. An increase of about $12.1 \mathrm{~mm}$ in length was achieved at each operation providing a mean total of $5.2 \mathrm{~cm}$ (Figs 6 to 8). Taking into account the additional lengthening achieved at the primary operation or at any revision, the mean total lengthening for the whole series was about $8.5 \mathrm{~cm}$. The first lengthening was on average performed 17.5 months (9 to 31) after the primary procedure. In four patients lengthening led to decreased movement and stiffness which required further courses of physiotherapy. Manipulation of the knee under anaesthesia was required for one patient.

At revision the prostheses had a smooth tubular pseudocapsule which was stained black by wear debris from the titanium. This capsular tissue has low elasticity and required circumferential incision or excision to allow further lengthening. The extensor mechanism of the patella, the patellar tendon and its attachment to the tibia were preserved in all but two patients. In these two the functional 


\begin{tabular}{|c|c|c|c|c|c|c|c|}
\hline $\begin{array}{l}\text { Revision } \\
\text { (mth after } \\
\text { primary) }\end{array}$ & Complications $\stackrel{\dagger}{\dagger}$ & $\begin{array}{l}\text { Knee } \\
\text { ROM } \\
\text { (degrees) }\end{array}$ & Pain & Ambulation§ & $\begin{array}{l}\text { Current } \\
\text { status } \rrbracket\end{array}$ & $\begin{array}{l}\text { Clinical } \\
\text { results } \\
(\%)\end{array}$ & Comments\| \\
\hline 103 & $\mathrm{PF}$ & 0 to 110 & - & IDP & $\mathrm{CDF}$ & 90/Excel & $\begin{array}{l}\text { Revision due to jammed extending mechanism in } \\
5.93\end{array}$ \\
\hline 63 & AL-FC & 0 to 105 & - & IDP & NED & 76/Good & $\begin{array}{l}\text { Revised to fixed-length prosthesis. Local recur- } \\
\text { rence excised in } 5.89\end{array}$ \\
\hline 41 & AL-FC & 0 to 95 & - & IDP & $\mathrm{CDF}$ & 86/Excel & \\
\hline- & - & 0 to 110 & - & IDP & $\mathrm{CDF}$ & 83/Excel & \\
\hline 68 & AL-TC & 0 to 100 & - & IDP & $\mathrm{CDF}$ & 76/Good & \\
\hline 67 & MEM & 5 to 95 & - & IDP & NED & 80/Excel & $\begin{array}{l}\mathrm{PM} \text { in 2.95. Prosthesis exchanged in } 6.96 \text { to } \\
\text { accomplish further growth }\end{array}$ \\
\hline 60 & MEM & 0 to 120 & - & IDP & $\mathrm{CDF}$ & 90/Excel & $\begin{array}{l}\text { Prosthesis exchanged in } 12.93 \text { to accomplish fur- } \\
\text { ther growth }\end{array}$ \\
\hline 92 & AL-FC & 0 to 100 & - & IDP & $\mathrm{CDF}$ & 83/Excel & $\begin{array}{l}\text { Revision in } 2.97 \text { to uncemented fixed-length } \\
\text { prosthesis }\end{array}$ \\
\hline 108 & FRC & 0 to 90 & - & IDP & NED & 73/Good & $\begin{array}{l}\mathrm{PM} \text { in } 11.93 \text {. Tibial stem revised in } 3.96 \text { due to } \\
\text { proximal tibial fracture }\end{array}$ \\
\hline 101 & AL-FC & 10 to 105 & - & HKB & $\mathrm{CDF}$ & 63/Fair & $\begin{array}{l}\text { Patellar tendon avulsion due to MUA reconstruc- } \\
\text { ted in } 5.96\end{array}$ \\
\hline 46 & AL-FC & 0 to 95 & - & IDP & $\mathrm{CDF}$ & 83/Excel & Revised to fixed-length prosthesis \\
\hline- & - & 5 to 90 & - & $\mathrm{EC}$ & $\mathrm{CDF}$ & 46/Fair & Surgery related common peroneal nerve palsy \\
\hline 74.9 & & 1.6 to 101 & & & & 77 & \\
\hline 8 & LR & 0 to 90 & ++ & HKB & NED & -/Poor & $\begin{array}{l}\text { PM in 12.90. Amputation due to local recurrence } \\
\text { in } 6.91\end{array}$ \\
\hline 0 & INF & 5 to 85 & - & FKB/WS & $\mathrm{CDF}$ & $-/$ Poor & Amputation due to chronic leg infection in 12.85 \\
\hline 0 & - & 0 to 65 & + & $\mathrm{EC}$ & $X$ & 56/Fair & $\begin{array}{l}\text { Died from complications related to pulm metasta- } \\
\text { sis in } 6.93\end{array}$ \\
\hline 0 & - & 0 to 90 & - & $\mathrm{EC}$ & $X$ & 73/Good & $\begin{array}{l}\text { Died from complications related to pulm metasta- } \\
\text { sis in } 11.90\end{array}$ \\
\hline 0 & - & 10 to 90 & - & IDP & $\mathrm{X}$ & 73/Good & $\begin{array}{l}\text { Died from complications related to bony and pulm } \\
\text { metastasis in } 12.91\end{array}$ \\
\hline 0 & - & 0 to 95 & - & IDP & $X$ & 83/Excel & $\begin{array}{l}\text { Died from complications related to bony and pulm } \\
\text { metastasis in } 10.89\end{array}$ \\
\hline
\end{tabular}

results were surprisingly good, perhaps because they had been kept in a straight-leg splint to allow the development of a layer of fibrous connective tissue before starting active mobilisation. At maturity our patients presented with a residual leg-length discrepancy of $1.5 \mathrm{~cm}$.

\section{DISCUSSION}

In our study the overall survival of patients after limb salvage was similar to that reported by other authors (Fig. 1a) but $12 \%$ higher than that in earlier series from our hospital. ${ }^{2,27,50,51}$ The rates of local recurrence were similar.

Table V gives a comparison with other studies of the use of extendible distal femoral replacements for malignant bone tumours. Revision of the prosthesis is to be expected in these children (Fig. 1b). Schiller et $\mathrm{al}^{27}$ had to revise three prostheses in five patients followed for a mean of 5.2 years, and then exchanged the extendible components to standard prostheses at maturity. Kenan and Lewis ${ }^{26}$ had a revision rate of $100 \%$ for patients followed up more than five years. The mean survival time of their revised replacements was 5.6 years.
Aseptic loosening appears to be the most important factor in the survival of the replacement (Figs $1 \mathrm{~b}$ and $9),{ }^{52,53}$ and is the most common complication, followed by mechanical failure, infection, maximisation of the extending mechanism, stress fracture around the intramedullary stem and local recurrence (Figs 10 and 11). In our patients, there was no aseptic loosening in the first three years, but thereafter six patients $(50 \%)$ developed clinical and radiological signs of loosening and required revision. Schiller et $\mathrm{al}^{27}$ found aseptic loosening in only $20 \%$ of their patients, whereas Kenan, Di Simone and Lewis ${ }^{54}$ encountered it in $60 \%$ within three to nine years of the primary operation. Contributing factors may be the reshaping of the femur during growth, the constrained character of the knee component, biochemical reactions to metal and polyethylene wear particles and the high physical demands of a young patient.

Constrained or semiconstrained knee replacements are required after tumour resection of the distal femur since all stabilising structures about the knee are either detached or resected. These components give an increase in shear and torque stress at the proximal and distal areas of 
fixation of the prosthesis as well as around the hingemechanism itself. This may contribute to aseptic loosening of the intramedullary stem directly as well as indirectly through an increase in the generation of wear particles of metal, polyethylene and acrylic. ${ }^{55}$ Attempts to use hemiarthroplasties created excessive knee movement, lack of control and chondrolysis of the tibial plateau and hence failed to produce acceptable survival and functional results.

The degree of offset of the prosthesis as judged by the distance between the tip of the femoral stem and the mechanical axis of the leg will also influence the bending forces and shear stress around the proximal endoprosthetic fixation. $^{56,57}$ Cannon $^{58}$ demonstrated a direct relationship between the amount of bone resected and implant failure due to aseptic loosening. This was particularly obvious when more than $60 \%$ of the distal femur had to be resected, an observation which is supported by our results. The development of bone-to-shaft incongruity may occur when the proximal stem of the prosthesis cannot enlarge to match the growth-related increase in the diameter of the medullary canal. This may be a particular problem in very young patients and in children below the age of ten years. At the primary operation we observed cranial migration of the cemented femoral stem after signs of aseptic loosening had appeared. Similar observations have been made in cases in which uncemented fixation was used. ${ }^{15,54}$

Direct failure of the main prosthetic replacements was not a problem, which confirms the durability and strength of the materials and mechanisms used. ${ }^{19,24,27,59}$ Some authors, however, have reported relatively high rates of failure with other types of extendible prosthesis. ${ }^{25,31}$

We did not usually find it necessary to revise the replacement after maximum lengthening had been achieved, but some surgeons advise conversion to a conventional fixedlength prosthesis at maturity. ${ }^{27}$ We believe that the extendible prosthesis should be strong enough to remain functional beyond the maturity of the patient. In very young children the original prosthesis, which normally allows extension by up to $12 \mathrm{~cm}$, may not allow sufficient longterm lengthening and will then require changing. ${ }^{54}$

Deep infection is usually managed with high doses of intravenous antibiotics and staged exchange of the prosthesis. We did not encounter this problem. Others have reported a similar experience, ${ }^{25,31,54}$ but infection rates of $20 \%$ to $40 \%$ have been described, ${ }^{24,27}$ particularly when a large number of operations have been performed.

Use of the well-established rating score system of the Musculoskeletal Tumor Society (Table I) ${ }^{46,47}$ has allowed better comparison of the results of different series, which have generally been encouraging. ${ }^{15,25,27,30}$ It was interesting to note that the functional results of the presented patients did not deteriorate with time or the circumstance of prosthetic revision (Fig. 12).

The first lengthening procedure is usually performed at least one year after the initial operation since chemo-

Table V. Comparison of studies concerning the use of extendible distal femoral replacements for malignant bone tumours

\begin{tabular}{|c|c|c|c|c|c|c|c|c|c|c|c|c|}
\hline & \multirow{2}{*}{$\begin{array}{l}\text { No of } \\
\text { cases* }\end{array}$} & \multirow{2}{*}{$\begin{array}{l}\text { Range of } \\
\text { follow-up } \\
(\mathbf{y r})\end{array}$} & \multirow{2}{*}{$\begin{array}{l}\text { Mean } \\
\text { follow-up } \\
(y \mathbf{y})\end{array}$} & \multirow{2}{*}{$\begin{array}{l}\text { Mean } \\
\text { amount of } \\
\text { operations } \\
\text { performed }\end{array}$} & \multicolumn{4}{|c|}{ Complications $(\%) \dagger$} & \multirow{2}{*}{$\begin{array}{l}\text { Amount of } \\
\text { revisions } \\
\text { performed } \\
(\%)\end{array}$} & \multirow{2}{*}{$\begin{array}{l}\text { Mean } \\
\text { survival } \\
\text { time of } \\
\text { revised } \\
\text { prostheses } \\
\text { (yr) }\end{array}$} & \multirow{2}{*}{\multicolumn{2}{|c|}{ Rating $\neq$ Comments }} \\
\hline & & & & & $\mathbf{A L}$ & $\mathbf{P F}$ & INF & Others & & & & \\
\hline $\begin{array}{l}\text { Kenan et al } \\
1991^{31}\end{array}$ & 15 & 1 to 4 & $x \S$ & $\mathrm{x}$ & 26.6 & - & - & - & 26.6 & $\mathrm{x}$ & & \\
\hline $\begin{array}{l}\text { Eckardt et al } \\
1993^{25}\end{array}$ & 7 & 1 to 3.4 & 2.4 & -3 & - & 57 & - & - & 14.2 & $\mathrm{x}$ & $\begin{array}{l}2 \mathrm{E} / 3 \mathrm{G} / \\
1 \mathrm{~F} / 1 \mathrm{P}\end{array}$ & $\begin{array}{l}\text { Prosthetic failure } \\
\text { occurred on average } \\
\text { after } 15 \text { months }\end{array}$ \\
\hline $\begin{array}{l}\text { Kenan et al } \\
1993^{54}\end{array}$ & 15 & 3 to 9 & $\mathrm{x}$ & $\mathrm{x}$ & 60 & - & - & 6.6 & 66.6 & $\mathrm{x}$ & $\begin{array}{l}3 \mathrm{E} / 2 \mathrm{G} / \\
4 \mathrm{~F} / 2 \mathrm{P}\end{array}$ & \\
\hline $\begin{array}{l}\text { Kenan and } \\
\text { Lewis } 1995^{26}\end{array}$ & 24 & 2 to 12 & $\mathrm{x}$ & $\mathrm{x}$ & $\mathrm{x}$ & $\mathrm{x}$ & $\mathrm{x}$ & $\mathrm{x}$ & $\mathrm{x}$ & 5.6 & $\mathrm{G} \rrbracket$ & $\begin{array}{l}\text { All patients with } \\
\text { follow-up }>5 \text { years } \\
\text { revised. } \\
\text { AL most common } \\
\text { cause for revision }\end{array}$ \\
\hline $\begin{array}{l}\text { Cool et al } \\
1995^{24}\end{array}$ & 15 & $>5$ & $\mathrm{x}$ & 12.7 & $\mathrm{x}$ & $\mathrm{x}$ & 20 & $\mathrm{x}$ & $\mathrm{x}$ & $\mathrm{x}$ & $72 \%$ & $\begin{array}{l}\text { AL most common } \\
\text { cause for revision } \\
\text { followed by INF }\end{array}$ \\
\hline $\begin{array}{l}\text { Schiller et al } \\
1995^{27}\end{array}$ & 5 & 4.6 to 6.1 & 5.2 & 10.6 & 20 & - & 40 & - & 60 & $\mathrm{x}$ & $\mathrm{E} / \mathrm{G} \uparrow$ & \\
\hline $\begin{array}{l}\text { Schindler et al } \\
\text { (present series) }\end{array}$ & 12 & 6.0 to 13.2 & 8.7 & 6.6 & 50 & 8.3 & - & 33 & 83 & 6.2 & $77 \%$ & \\
\hline
\end{tabular}

* number of patients with extendible distal femoral replacement

$\dagger \mathrm{AL}$, aseptic loosening; PF, prosthetic failure; INF, infection

₹ rating system based on the Musculoskeletal Tumor Society scores: E, excellent; G, good; F, fair; P, poor (see text)

$\S$ not reported

I unspecified individual rating scores 


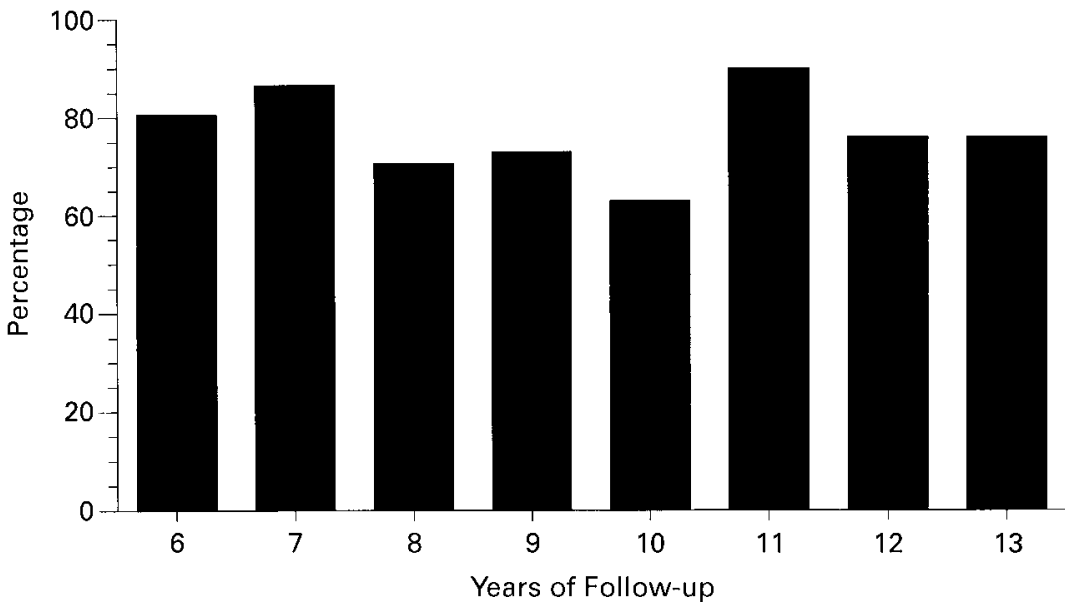

Fig. 12

The clinical end results according to the MTSRS score. The percentage is the proportion of expected normal function.

therapy seems to slow down growth transiently and makes earlier intervention unnecessary. ${ }^{31,60,61}$ Active lengthening, which in our series began on average 17.5 months after the primary surgery, does not seem to influence the clinical outcome, although prosthetic extension can temporarily impair functional abilities. Most reports show an average gain of 1 to $2 \mathrm{~cm}$ for each extension, but the total amounts vary considerably between 2.0 and $13.1 \mathrm{~cm} .^{27,31,59,60}$ This wide range may result from differences in measuring technique or the inclusion of the lengthening achieved at the time of primary implantation and revision. The mean shortening of about $1.5 \mathrm{~cm}$ at maturity in our patients did not seem to be a functional disadvantage; some found it easier to walk with a slightly shorter leg, presumably because it was easier for the 'disabled' leg to swing through. ${ }^{31}$

The development of a black-stained pseudocapsule surrounding endoprosthetic replacements predominantly made of titanium has been widely reported, ${ }^{14,27,54,60,62}$ and the tubular scar with its smooth and glossy appearance is recognised as a fibroblastic response to titanium wear particles. This tissue reaction varies with the amount of particles generated and may lead to tissue necrosis, ${ }^{63}$ although we did not see this. Our currently used Stanmore Mark IV replacements now have a complete surface coating to decrease the release of titanium particles. Alternatively, the administration of cortisone or indomethacin has been advocated, ${ }^{62}$ but no convincing results confirming the effectiveness of any prophylactic treatment to decrease tubular scar formation have yet been published.

Conclusions. In our experience extendible distal femoral replacements offer the skeletally immature individual a reliable and viable alternative to above-knee amputation in appropriate cases. No attempts, however, should be made to achieve limb-sparing surgery by compromising safe margins of resection as a means of local tumour control and long-term survival. Limb preservation allows immediate functional restoration, rapid rehabilitation, and improvement in quality of life, although knee function and mobility can be temporarily impaired after prosthetic lengthening. ${ }^{17}$

Despite obvious benefits children are exposed to multiple surgical procedures which all carry various risks. Prosthetic survival is predominantly limited because of the occurrence of aseptic loosening of the femoral fixation and the limitations of durability. We therefore believe that the high rate of prosthetic revision in the demanding group of children should be regarded as a 'physiological complication' or necessity. With the currently available prosthetic replacements and implantation techniques, satisfactory mediumterm results are achievable but yet no final judgement can be given to date regarding functional end-results and delayed morbidity. Careful selection of patients and realistic appraisal of the long-term prospects are essential for successful treatment.

We wish to acknowledge the contributions made by Mr Justin Cobb, (London), Mr John Spivey, (Oxford), and Mr Brian Hurson, (Dublin). We also appreciate the support given by Ronald Ansall and Neil Balmer of the Department of Biomedical Engineering, Dirk de Camp of the Medical Photography Department and the Bone Tumour secretaries Patricia Barker and Tracy Tarr. We also thank Sarah-Ann Gillies for her dedication and support during the development of this project.

No benefits in any form have been received or will be received from a commercial party related directly or indirectly to the subject of this article.

\section{REFERENCES}

1. O'Flanagan SJ, Stack JP, Mcgee IIMJ, Dervan P, Hurson B. Imaging of intramedullary tumour spread in osteosarcoma. $J$ Bone Joint Surg [Br] 1991;73-B:998-1001.

2. Simon MA, Aschiliman MA, Thomas N, Mankin HJ. Limb-salvage treatment versus amputation for osteosarcoma of the distal end of the femur. J Bone Joint Surg [Am] 1986;68-A:1331-7.

3. Goorin AM, Andersen JW. Experience with multiagent chemotherapy for osteosarcoma. Clin Orthop 1991;270:22-8.

4. Lewis MM. An approach to the treatment of malignant bone tumors. Orthopedics 1985;8:655-6.

5. Link MP, Goorin AM, Miser AW, et al. The effect of adjuvant chemotherapy on relapse-free survival in patients with osteosarcoma of the extremity. New Eng J Med 1986;134:1600-6.

6. Nilsonne U. Limb-preserving radical surgery for malignant bone tumours. Clin Orthop 1984;191:21-6.

7. Rao BN, Champion JE, Pratt CB, et al. Limb salvage procedures for children with osteosarcoma: an alternative to amputation. J Pediatr Surg 1983;18:901-8. 
8. Rosen G, Murphy ML, Huvos AG, Gutierrez M, Marcove RC. Chemotherapy, en bloc resection, and prosthetic bone replacement in the treatment of osteogenic sarcoma. Cancer 1976;37:1-11.

9. Rougraff BT, Simon MA, Kneisl JS, Greenberg DB, Mankin HJ. Limb-salvage compared with amputation for osteosarcoma of the distal end of the femur. J Bone Joint Surg [Am] 1994;76:649-56.

10. Springfield D, Schmidt R, Graham-Pole J, et al. Surgical treatment for osteosarcoma. J Bone Joint Surg [Am] 1988;70-A:1124-30.

11. Kemp HBS. Limb conservation surgery for osteosarcoma and other primary bone tumours. In: Bailliere's clinical oncology: bone tumours. Vol. 1. London: Bailliere Tindall, 1987;1:111-36.

12. McDonald DJ. Current concepts of treatment of bone tumors. In Schajovicz F, ed. Tumors and tumorlike lesions of bone: pathology, radiology and treatment. New York: Springer-Verlag, 1994:613-43.

13. Kropej D, Sciller C, Ritschil P, Salzer-Kuntschik M, Kotz R. The management of 11B osteosarcoma: experience from 1976 to 1985. Clin Orthop 1991;230:40-4.

14. Lewis MM, Bloom N, Esquieres EM, Kenan S, Ryniker DM. The expandable prosthesis: an alternative to amputation for children with malignant bone tumours. AORN J 1987;46:457-70.

15. Ward WG, Yang RS, Eckardt JJ. Endoprosthetic bone reconstruction following malignant tumor resection in skeletally immature patients. Orthop Clin North Am 1996;27:493-502.

16. Lewis MM. The use of an expandable and adjustable prosthesis in the treatment of childhood malignant bone tumours of the extremity. Cancer 1986;57:499-502.

17. Scales JT, Sneath RS. The extending prosthesis. In: Coombs R Friedlaender G, eds. Bone tumour management. London: Butterworths, 1987:168-77.

18. Harris IE, Leff AR, Gitelis S, Simon MA. Function after amputation arthrodesis, or arthroplasty for tumors about the knee. J Bone Joint Surg [Am] 1990;72-A:1477-85.

19. Otis JC, Lane JM, Kroll MA. Energy cost during gait in osteosarcoma patients after resection and knee replacement and after abovethe-knee amputation. J Bone Joint Surg [Am] 1985;67-A:606-11.

20. May DRW, Walker PS. Design and follow-up of extending prosthetic replacements for children. In: Brown KLB, ed. Complications of limb salvage: prevention, management and outcome. Montreal: ISOLS, 1991:505-10.

21. Scales JT, Sneath RS, Wright KWJ. Design and clinical use of extending prostheses. In: Enneking WF, ed. Limb salvage in musculoskeletal oncology. New York, etc: Churchill Livingstone, 1987 52-61.

22. Van Krieken FM, Hartel RM, van Campen DH, et al. A growthimitating lengthening element for modular femoral endoprostheses. In: Enneking WF, ed. Limb salvage in musculoskeletal oncology. New York, etc: Churchill Livingstone, 1987:613-5.

23. Verkerke B, Schraffordt-Koops H, Veth RP, Postma L, Grootenboer HJ. A modular endoprosthetic system, noninvasively extendable for young patients with osteosarcoma. Cancer Treat Res 1993; 62:213-20.

24. Cool WP, Grimer RJ, Carter SR, Sneath RS, Walker PS. The outcome of extensible endoprosthetic replacements of the proximal tibia and distal femur. Florence. Procs 8th International Symposium on Limb Salvage (ISOLS) 1995:126.

25. Eckardt JJ, Safran MR, Eilber FR, Rosen G, Kabo JM. Expandable endoprosthetic reconstruction of the skeletally immature after malignant bone tumor resection. Clin Orthop 1993;297:188-202.

26. Kenan S, Lewis MM. Limb sparing surgery in children: the extendible prosthesis. Current trends and controversies after the first ten years. Florence. Procs 8th International Symposium on Limb Salvage (ISOLS) 1995:124.

27. Schiller $\mathbf{C}$, Windhager $\mathbf{R}$, Fellinger $\mathbf{E}$, et al. Extendable tumour endoprosthesis for the leg in children. J Bone Joint Surg [Br] 1995; 77-B:608-14.

28. Bradish CF, Kemp HBS, Scales JT, Wilson JN. Distal femoral replacement by custom-made prostheses. J Bone Joint Surg [Br] 1987 69-B:276-84

29. Roberts P, Chan D, Grimer RJ, Sneath RS, Scales JT. Prosthetic replacement of the distal femur for primary bone tumors. J Bone Joint Surg [Br] 1991;73-B:762-9.

30. Frieden RA, Ryniker D, Kenan S, Lewis MM. Assessment of patient function after limb-sparing surgery. Arch Phys Med Rehabil 1993; $74: 38-43$.
31. Kenan S, Bloom N, Lewis MM. Limb-sparing surgery in skeletally immature patients with osteosarcoma: the use of an expandable prosthesis. Clin Orthop 1991;270:223-30.

32. Kenan S, Lewis MM. Limb salvage in pediatric surgery: the use of extendable prosthesis. Orthop Clin N Am 1991;22:121-31.

33. Enneking WF. A system of staging musculoskeletal neoplasms. Clin Orthop 1986;204:9-24.

34. Galasko CSB. Skeletal scintigraphy. In: Coombs R, Friedlaender G, eds. Bone tumour management. London: Butterworths, 1987:57-67.

35. Taminiav AHM, Bloem JL. The impact of MRI on staging malignant musculoskeletal tumors. In: Yamamuro T, ed. New development for limb salvage in musculoskeletal tumors. Tokyo: Springer-Verlag, 1989:133-5.

36. Zimmer WD, Berquist TH, McLeod RA, et al. Magnetic resonance imaging of osteosarcoma: comparison with computed tomography. Clin Orthop 1986;208:289-99.

37. Coombs R, Halliday K. Biopsy techniques. In: Coombs R, Friedlaender G, eds. Bone tumour management. London: Butterworths, 1987 81-7.

38. Simon MA, Bierman JS. Biopsy of bone and soft-tissue lesions. J Bone Joint Surg [Am] 1993;75-A:616-21.

39. Stoker DJ, Cobb JP, Pringle JAS. Needle biopsy of musculoskeletal lesions: a review of 208 procedures. J Bone Joint Surg [Br] 1991; 73-B:498-500.

40. Enneking WF, Spanier SS, Goodman MA. A system for the surgica staging of musculoskeletal sarcoma. Clin Orthop 1980;153:106-20.

41. Coutts RD. The use of continuous passive motion in the rehabilitation of orthopaedic problems. Contemp Orthop 1988;16:75-106.

42. Armitage P. Statistical methods in medical research. Oxford, etc: Blackwell Scientific, 1971:408-14.

43. Tew M, Waugh W. Estimating the survival time of knee replacements. J Bone Joint Surg [Br] 1982;64-B:579-82.

44. Bradford-Hill Sir A. Life tables and survival after treatment. In: Bradford-Hill Sir A, ed. Principles of medical statistics. Ninth edition. London: The Lancet Limited 1971;220-36.

45. Kaplan EL, Meier P. Nonparametric estimation from incomplete observations. J Am Stat Assoc 1958;53:457-81.

46. Enneking WF. Modification of the system for functional evaluation of surgical management of musculoskeletal tumors. In: Enneking WF, ed. Limb salvage in musculoskeletal oncology. New York: Churchill Livingstone, 1987:626-39.

47. Enneking WF, Dunham W, Gebhardt MC, Malawar M, Pritchard DJ. A system for the functional evaluation of reconstructive procedures after surgical treatment of tumours of the musculoskeletal system. Clin Orthop 1993;286:241-6.

48. Inglis AE Jr, Walker PS, Sneath RS, Grimer R, Scales JT Uncemented intramedullary fixation of implants using polyethylene sleeves: a roentgengraphic study. Clin Orthop 1992;284:208-14.

49. Walker PS, Emerson R, Potter T, et al. The kinematic rotating hinge: biomechanics and clinical application. Orthop Clin North Am 1982;13:187-99.

50. Cobb JP, Cannon SR, Sweetnam DR, Kemp HBS. Distal femoral limb salvage 10 years on. In: Brown KLB, ed. Complications of limb salvage: prevention, management and outcome. Montreal: ISOLS, 1991:467-72.

51. Makley JT, Krailo M, Ertel IJ, et al. The relationship of various aspects of surgical management to outcome in childhood non-metastatic osteosarcoma. J Pediatr Surg 1988;23:146-51.

52. Unwin PS, Cannon SR, Grimer RJ, et al. Aseptic loosening in cemented custom-made replacements for bone tumours of the lowe limb. J Bone Joine Surg [Br] 1996;78-B:5-13.

53. Ward WG, Eckardt JJ, Johnston-Jones KS, et al. Five to ten year results of custom endoprosthetic replacement for tumors of the distal femur. In: Brown KLB, ed. Complications of limb salvage: prevention, management and outcome. Montreal: ISOLS, 1991:483-91.

54. Kenan S, DeSimone DP, Lewis MM. Limb sparing for skeletally immature patients with osteosarcoma: the expandable prosthesis. Cancer Treat Res 1993;62:205-11.

55. Howie DW, Haynes DR, Rogers SD, McGee MA, Pearcy MJ. The response to particulate debris. Orthop Clin North Am 1993; 24 $571-81$. 
56. Unwin PS, Cobb JP, Walker PS. Loosening in cemented femoral prostheses: a study of 668 tumour cases. In: Brown KLB, ed. Complications of limb salvage: prevention, management and outcome. Montreal: ISOLS, 1991:133-7.

57. Taylor S, Perry J, Adler J, Unwin PS, Walker PS. The telemetry of forces in vivo developed in massive orthopaedic implants: the first 18 months, results from walking. In: Tan SK, ed. Limb salvage: current trends. Singapore: ISOLS, 1993:560.

58. Cannon SR. Massive prostheses for malignant bone tumours of the limbs: Instructional Course Lecture. J Bone Joint Surg [Br] 1997; 79-B:497-506.

59. Schindler OS, Cannon SR, Briggs TWR. Clinical experience with Stanmore extendible prosthetic distal femoral replacements in growing individuals with primary malignant bone tumours. J Bone Joint Surg [Br] 1997;79-B:Suppl 1:97.
60. Eckardt JJ, Eilber FR, Rosen G, et al. Endoprosthetic replacement for stage IIB osteosarcoma. Clin Orthop 1991;270:202-13.

61. Glasser DB, Duane K, Lane JM, Healey JH, Caparros-Sison B. The effect of chemotherapy on growth in the skeletally immature individual. Clin Orthop 1991;262:93-100.

62. Windhager R, Schiller CH, Giesinger B, Kotz R. Complications and problems with expandable prostheses in children: treatment and prophylaxis. In: Brown KLB, ed. Complications of limb salvage: prevenphylaxis. In: Brown KLB, ed. Complications of limb salvage: preve
tion, management and outcome. Montreal: ISOLS, 1991:511-3.

63. Blunn GW, Wait ME, Lilley P, Walker PS. The reactions of tissues to titanium wear generated from massive segmental bone defect prostheses. In: Brown KLB, ed. Complications of limb salvage: prevention, management and outcome. Montreal: ISOLS, 1991: 429-32. 